Apidologie, 1983, 14 (4), 299-302.

\title{
EXAMINATION OF FLORAL NECTAR OF CITRUS, COTTON, AND ARIZONA DESERT PLANTS FOR MICROBES
}

\author{
U.S. Department of Agriculture \\ Agricultural Research Service \\ Carl Hayden Bee Research Center \\ 2000 East Allen Road \\ Tucson. Arizona 85719
}

Martha GILLIAM, Joseph O. MOFFETT (1), and N. M. KAUFFELD

\section{SUMMARY}

Floral nectar from 3 cultivars of fieid-grown cotton, 9 cultivars of cotton grown in a greenhouse. 5 cultivars of citrus, saguaro cactus, and prickly pear cactus were examined for bacteria, yeasts, and molds by plating on selective microbiological media. No microbes were isolated from nectar of any cotton flowers. Of 23 samples of citrus nectar, 3 contained a few gram-negative rod-shaped bacteria. Nectar from prickly pear cactus contained no microbes, although nectar from saguaro cactus contained a few bacteria (gram-negative rods, gram-positive rods, and gram-positive cocci). These results are discussed in relation to possible antimicrobial substances in nectar as well as the origin of the microflora of honey bees.

Nectar samples from selected plants attractive to honey bees, Apis mellifera L., were found to be devoid of yeasts (GILLIAM, 1975). Nectar from saguaro cactus (Cereus giganteus Engelm.) contained Staphylococcus spp. as well as gram-positive and gram-negative rod-shaped bacteria. Only 9 of 50 nectar samples from 5 Citrus cultivars contained microbes (bacteria, a fungus, and an actinomycete). From this work, it appeared that nectar is not a major source of microflora for honey bees. In the present work, we examined additional nectar samples, mostly from different species than were examined previously, for microbes.

(1) Present Address: USDA, ARS, Plant Science Research Laboratory, P. O. Box 1029, Stillwater, OK 74076 . 
Samples of floral nectar from 3 cultivars of field-grown cotton from Marana and Sacaton, Arizona; 9 cultivars of cotton grown in a greenhouse; 5 cultivars of citrus growing in Yuma, Arizona; and 2 desert plants from Tucson were collected in 10- $\mu$ l capillary pipets that were sealed and placed in vials on dry ice, then transferred to the laboratory. Care was taken to avoid any contamination by pollen. Samples that were not plated immediately were stored for short periods in a refrigerator. Sterile pipets were used for all collections except nectar from cotton. Flowers of field-grown cotton and citrus were isolated from honey bees by screening or bagging for 24 hours before collections were made.

Nectar was collected from field-grown cotton (Gossypium spp.) cultivars of Deltapine 16 and 61 and A-line Stoneville 213. In addition to nectar from untreated plants, samples were also obtained from plants which had been sprayed with 2,4-D (Gilliam et al., 1981). A total of 20 samples from Deltapine 16, 20 from A-line Stoneville 213, and 4 from Deltapine 61 were examined.

Greenhouse-grown cultivars of cotton examined were DPL-70, Stoneville 213 , Stoneville 825, Glandless Acala 73-64, Hopicala, Pima S-5, G. herbaceum L., and 2 hexaploids. Approximately $20 \mu \mathrm{l}$ of nectar per cultivar were examined.

Samples of citrus nectar were collected from Marsh grapefruit, Red Blush grapefruit, Valencia orange, Hamlin orange, and Minneola tangelo. Four or 5 tubes of nectar were collected from each citrus cultivar for examination.

Nectar from desert plants was collected from saguaro cactus ( 12 flowers from plants at 3 locations) and prickly pear cactus (Opuntia sp.; from 2 flowers each of the same flat-stemmed species at 2 locations).

Samples were plated in duplicate on Czapek solution agar (Difco) ${ }^{2}$, YM-1 agar (WICKERHAM, 1951), and nutrient agar (Difco) in petri dishes to isolate molds, yeasts, and bacteria. All samples except those from greenhouse-grown cotton were also plated on YM-20 (GILLIAM, 1975) to test for the presence of osmophilic species and were inoculated into duplicate tubes of thioglycollate medium without indicator (Difco) to test for anaerobes. One plate or tube of each medium was incubated at $25{ }^{\circ} \mathrm{C}$ and the other at $37{ }^{\circ} \mathrm{C}$ under aerobic conditions except for samples from cotton grown in the greenhouse which were all incubated at $37{ }^{\circ} \mathrm{C}$. During à 2-week incubation period, plates and tubes were periodically examined for microbial growth, and any colonies that developed were stained by the gram method and examined microscopically.

No microorganisms were isolated from the nectar of cotton flowers using our selection of culture media. This may be due to the fact that cotton flowers normally bloom for only one day, opening in the morning and closing in the late

(2) Mention of a proprietary product in this paper does not constitute an endorsement of this product by the USDA. 
afternoon. All samples were collected after 1 p.m. In addition, the floral nectar of cotton is well protected by the structure of the base of the petals and also by the bracts of the flower and thus may not be readily exposed to microbial contamination. Therefore, microbes are probably not responsible for differences in amino acids (GILLIAM et al., 1981) or sugars (BUTLER et al., 1972) of cotton nectar. This is an important evolutionary aspect of nectar chemistry since use, addition, and/or degradation of amino acids or fermentation of sugars by microbes could interfere with the attraction and nutritive value of nectar for honey bees and other flower visitors. Antimicrobial substances may abound in cotton nectar; the absence of microbes in our samples, which were not collected with sterile technique, points to this possibility. Indeed, bees use antimicrobial systems to protect their stores of honey and bee bread, and honey is known to contain antibacterial compounds (see BURGETT, 1978). However, some of these compounds appear to be introduced by the bees during the conversion of nectar into honey. Thus, floral nectar should be examined for antimicrobial compounds that may differ from those found in honey. Also, extrafloral nectar of cotton might be a more likely source of microbes since the nectaries are more exposed and secrete nectar for several days.

Of 23 tubes of nectar obtained from the citrus cultivars, only 3 samples, one each of nectar from Marsh grapefruit, Red Blush grapefruit, and Minneola tangelo, yielded microbes (small humbers of gram-negative rod-shaped bacteria). Thus, earlier work (GILLIAM, 1975) showing that microbes are not prevalent in citrus nectar is confirmed. Because citrus flowers remain open for about 3 days and are thus exposed to contamination from wind, thrips, and other insects, some nectar samples probably will be positive for microorganisms.

Nectar from prickly pear cactus contained no microbes. Honey bees seldom visit this plant for nectar, although other bees regularly collect the nectar. On the other hand, all nectar samples from saguaro cactus, an excellent source of nectar for honey bees, contained a few gram-negative rod-shaped bacteria, and 10 of the 12 samples also contained a few gram-positive rods as well as gram-positive cocci. These findings are in agreement with earlier results (GILLIAM, 1975) and may be due to contamination of the copious amounts of nectar by other flower visitors such as wild bees, birds, and bats since the flowers usually open at night and close the following afternoon.

Honey bees appear to be seeded microbiologically by pollen consumption and by other bees in the colony through trophallactic food exchange. Nectar seems to play a minor, if any, role in this process because of the paucity of microbes and the fact that antimicrobial systems operate as the process of conversion to honey takes place. 


\title{
RÉSUME \\ RECHERCHES DE MICROBES DANS LE NECTAR FLORAL DES AGRUMES, DU COTON FT DES PLANTES DESERTIQUES DE L'ARIZONA
}

On a recherché la présence de bactéries, de levures et de moisissures dans le nectar floral de 3 variétés de coton cultivées en champ, de 9 variétés de coton cultivées sous serre, de 5 variétés d'agrumes, du cactus géant (Cereus giganteus) et du figuier de Barbarie, en utilisant des milieux microbiologiques sélectifs. Aucun microbe n'a été isolé des nectars de coton. Seuls 3 des 23 échantillons du nectar d'agrumes étudiés renfermaient quelques bactéries en forme de batonnets à grain négatif. Le nectar de figuier de Barbarie ne contenait aucun microbe, mais celui de cactus géant possédaient quelques bactéries (bâtonnets à gram négatif et gram positif et coccus à gram positif).

On discute ces résultats par rapport à d'éventuelles substances antimicrobiennes présentes dans le nectar et à l'origine de la microflore des abeilles. Il ressort des résultats de cette étude et de nos travaux antérieurs que les abeilles sont contaminées microbiologiquement par la consommation de pollen et par les autres abeilles de la colonie lors des échanges de nourriture. Le nectar ne semble jouer, au plus, qu'un rôle mineur dans ce processus.

\section{ZUSAMMENFASSUNG}

\author{
UNTERSUCHUNG VON BLÜTENNEKTAR VON CITRUS. BAUMWOLLE \\ UND VON WÜSTENPFLANZEN IN ARIZONA AUF MIKROBEN
}

Blütennektar von 3 Sorten Baumwolle aus dem Freiland, 9 Sorten Baumwolle aus dem Glashaus, von 5 Citrus-Sorten, und von Saguaro und «prickly pear »- Kaktus wurden auf Bakterien, Hefen und Schimmelpilze durch Ausstreichen auf spezifischen mikrobiologischen Nährböden untersucht. Aus Nektar der Baumwollblüten wurden keinerlei Mikroben isoliert. Nur 3 Proben von 23 des Citrus-Nektars enthielten einige gram-negative, stäbchenförmige Bakterien. Der Nektar des " prickly pear » - Kaktus enthielt keine Mikroben, während im Nektar des Saguaro-Kaktus einige Bakterien (gram-negative und gram-positive Stäbchen und gram-positive Kokken) gefunden wurden. Diese Ergebnisse werden in Hinsicht auf mögliche antimikrobielle Substanzen im Nektar sowie auf die Herkunft der Mikroflora der Honigbiene diskutiert. Nach den Befunden dieser Untersuchung und aus unseren früheren Arbeiten scheint hervorzugehen, daß die Verbreitung mikrobieller Keime durch den Pollenverzehr und durch andere Bienen des Volkes beim Futteraustausch erfolgt. Nektar scheint bei diesem Prozess nur eine geringe oder gar keine Rolle zu spielen.

\section{REFERENCES}

Burgett D. M., 1978. - Antibiotic systems in honey, nectar, and pollen. In "Honey Bee Pests, Predators, and Diseases", ed. R. A. Morse, 297-308, Cornell University Press, Ithaca.

Butler G. D. Jr., Loper G. M., McGregor S. E., Webster J. L., Margolis H., 1972. - Amounts and kinds of sugars in the nectars of cotton (Gossypium spp.) and the time of their secretion. Agron. J., 64, 364-368.

GiLliAM M., 1975. - The absence of yeasts in nectars of selected Arizona plants attractive to honey bees, Apis mellifera. Ann. Entomol. Soc. Amer., 68, 705-706.

Gill.i.n M., McCalghey W. F. Moffett J. O., 1981. - Amino acids in the floral nectar of cotton. Apidologie, 12, 125-132.

Wickrrham L. J., 1951. - Taxonomy of yeasts. U.S. Dept. Agric. Bull., 1029. 